\title{
Linguistic Analysis of the Simultaneity Conjunctions of the Russian and Persian Languages
}

\section{Shafaghi Maryam ${ }^{1}$}

Associate Professor of the Russian language, Allame Tabatabae'i University, Tehran, Iran.

\author{
Goryachkovskaya Tatiana Dmitrievna ${ }^{2}$ \\ Master of Persian language Translation and Interpreting, \\ Moscow State Linguistic University, \\ Moscow, Russia. \\ (date of receiving: September 2020; date of acceptance: January, 2021)
}

\begin{abstract}
This article examines the problem of comparing the simultaneity conjunctions of the Russian and Persian languages within the framework of practical stylistics, which has not been previously analyzed by other researchers in separate works. Despite the difference in the quantitative indicators of the apparatus of the simultaneity conjunctions of the Russian and Persian languages, on both sides the target language has an adequate stylistic equivalent of the union of the simultaneity of the original language. The main content of the study is the analysis of texts of different styles in Russian and Persian languages, as well as works on the syntax of the languages under consideration, in order to compile an adequate description of the apparatus of simultaneity conjunctions and further linguistic analysis. As a result, specific equivalent conjunctions are identified that are most relevant for a particular style of speech. In the Persian language, the difficulty of making subordinate conjunctions with the $\_[\mathrm{ke}]$ part mainly lies in the existence of different spellings of the same conjunction word. In Russian, "when" is a high-frequency temporal conjunction. This lexeme can play the role of a conjunction, particle and temporary adverb.
\end{abstract}

Keywords: Subordinate Clause, Subordinate Conjunction, Translation Equivalence, Practical Style, Simultaneous Action.

1. E-mail: shafaghi@atu.ac.ir, maryam.shafaghi@mail.ru

2. E-mail: tatyana.goryachkovskaya@mail.ru 


\section{Лингвостилистический анализ союзов одновременности русского и персидского языков}

\section{Шафаги Марьям ${ }^{1}$}

Доцент кафедры русского языка университета им. Алламе Табатабаи, Тегеран, Иран.

Горячковская Татьяна Дмитриевна ${ }^{2}$

Магистр, Московский государственный лингвистический университет, Москва, Россия.

(дата получения: сентябрь 2020 г.; дата принятия: январь 2021 г.)

\section{Аннотация}

В данной статье рассматривается проблема сопоставления союзов одновременности русского и персидского языков в рамках практической стилистики, что ранее не анализировалось другими исследователями. Несмотря на разницу квантитативных показателей аппаратов союзов одновременности русского и персидского языков, с обеих сторон язык перевода имеет адекватный стилистический эквивалент союза одновременности исходного языка.

Основное содержание исследования составляет анализ текстов разных стилей на русском и персидском языках, а также работ, посвященных синтаксису рассматриваемых языков, с целью составления адекватного описания аппаратов союзов одновременности и дальнейшего лингвостилистического анализа. В результате выделены конкретные эквивалентные союзы, наиболее актуальные для того или иного стиля речи.

В персидском языке сложность составления подчинительных союзов с частью $\sim[k e]$ что заключается в основном в существовании различных вариантов написания одного и того же союзного слова. В русском языке «когда» является высокочастотным темпоральным союзом. Данная лексема может сыграть роль союза, частицы и временного наречия.

Ключевые слова: Придаточное Предложение, Подчинительный Союз, Переводческая Эквивалентность, Практическая Стилистика, Одновременное Действие.

1. E-mail: shafaghi@atu.ac.ir, maryam.shafaghi@mail.ru

2. E-mail: tatyana.goryachkovskaya@mail.ru 


\section{Введение}

Репрезентация временных отношений в рамках сложноподчиненного предложения, в частности, отношения одновременности, является существенным компонентом связной речи на любом языке. Статистический анализ текстов на русском и персидском языках демонстрирует, что темпоральные союзы доминируют в языковой среде: в персидском языке временные союзы наиболее многочисленны в ряду других подчинительных союзов, в русском же языке на каждый союз одновременности приходится несколько значений и функций.

В настоящей статье рассматривается стилистическая сторона союзов одновременности русского и персидского языков, производится их стилистический анализ и сопоставление, что иллюстрируется примерами из текстов различных стилей речи. После полного списка союзов одновременности в обоих языках предлагается их сопоставление с точки зрениях разговорного и книжных стилей.

Вопрос изучения союзов одновременности персидского языка поднимался как в XX, так и в XXI веке в работах филологов-специалистов по служебным частям речи Х. Халил-Рахбара (1988) и Х. Эбрахими (2009), и менее детально рассматривался в общих трудах по грамматике Ю.А. Рубинчика (2001), Х. Фаршидварда (2003), Т. Вахидиян-Камияра (2018) и др.

Для тщательного изучения союзов одновременности русского языка были использованы словари служебных слов А.Ф. Прияткиной (2001), Т.Ф. Ефремовой (2004) и В.В. Бурцевой (2005), а также работы по синтаксису В.В. Виноградова (1960),В.А. Белошапковой (1989), Н.С. Валгиной (2000 и 2002), совместный проект В.Ю. Апресян и О.Е. Пекелис (2012) и др.

В целях составления массива речевого материала для дальнейшего практического анализа широко использовался метод наблюдения, в т.ч. включенного наблюдения за носителями персидского языка; было собрано 
более 1500 примеров текстов, имеющих хотя бы одну из лексем, отобранных из теоретической литературы: одна треть примеров относилась к разговорной речи, две трети - к какому-либо из книжных стилей. Массив данных для разбора материала на русском языке был получен из Национального корпуса русского языка. По результатам анализа полученных данных было проведено сопоставление с имеющимся теоретическим материалом и обобщение полученных данных в тексте настоящего исследования.

Целью данной работы является поиск адекватных стилистических эквивалентов союзов одновременности русского и персидского языков путем анализа имеющегося теоретического материала, отражающего проблему исследования, исследования аппаратов союзов одновременности обоих языков и представления соответствующей системы сопоставления рассматриваемых лексем. Мы рассматриваем лингвостилистический компаративный анализ союзов одновременности, так как именно лингвостилистический уровень языка наиболее важен при подборе верного эквивалента в рамках адекватного перевода.

Данное исследование актуально для российских и иранских лингвистов, филологов и переводчиков, а также для других исследователей, чья деятельность связана с указанными языками, так как может помочь в поиске корректных стилистических эквивалентов в неродном языке.

Существует ряд работ, по отдельности затрагивающих тему союзов одновременности русского и персидского языков, однако в настоящей работе впервые производится стилистическое сопоставление союзов одновременности этих языков.

\section{1. Союзы одновременности в персидском языке}

Персидский язык располагает разветвленной базой сочинительных и подчинительных союзов. В ряду последних темпоральные союзы превалируют 
над остальными по количеству. Такое явление наблюдается в первую очередь из-за исторически сложившейся широкой системы синонимов-дублетов не только в обиходной лексике, но и в служебных частях речи персидского языка, обладающего внушительными внутренними возможностями продуцирования новых отыменных предлогов и союзов. Наличие подобных возможностей наблюдается и в русском языке, но в меньшей квантитативной репрезентации.

Сложность составления списка всех союзов одновременности связана с двумя основными факторами: по причине существования различных вариантов написания большинства сложных союзов, включающих в себя универсальный подчинительный союз ك $[k e]$ что, а также в связи со стилистической синонимичностью некоторых союзов. Кроме того, в состав абсолютного большинства подобных подчинительных сочетаний на взаимозаменяемой основе входят указательные местоимения اين آن آن [in] (Фаршидвард 2013. 550). В свою очередь, в некоторых союзах возможно

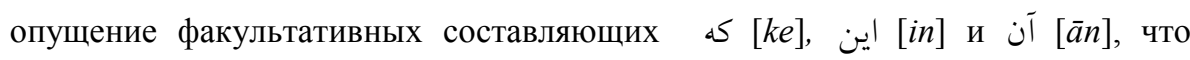
дополнительно расширяет диапазон вариантов написания множества подчинительных союзов.

Кроме того, мы исключаем из нашей выборки сочинительные союзы, которые также могут вводить одновременные действия, а фокусируем свое внимание на изначально темпоральных лексемах, которые встречаются лишь в системе подчинительных союзов.

Российский иранист Ю.А. Рубинчик перечисляет следующие временны́ союзы, которые вводят придаточные одновременности: وقتى كه و 2 vaqti-ke] когда, а также его упрощенная форма وقتى] موقعى كه, [mowqe'i-ke] когда, [dar-hāli-ke] 8

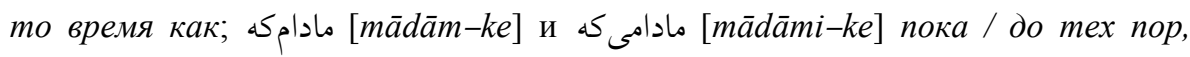

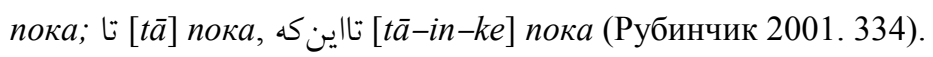




\section{1 - Союзы-синонимы وقتى كه [vaqti-ke]}

Х. Эбрахими поясняет, что данные слова обычно демонстрируют, что два или большее количество действий совершаются одновременно, но возможна как их полная, так и неполная одновременность». Он приводит синонимичные союзы одновременности هنخامى [hengāmi-ke], وقتى كه [vaqti-ke],

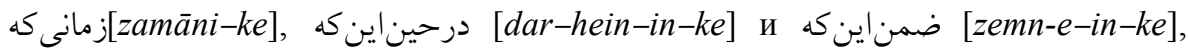
каждый из которых переводится на русский язык как когда (Эбрахими 1973. 43).

В персидском языке эти союзы могут выражать как повторяемые, так и однократные действия различной длительности. Вместе (также включая [mowqe’i-ke] когдa) они образуют ряд союзных темпоральных синонимов, которые могут употребляться в большинстве времен изъявительного и условного наклонения. Стоит отметить, что в придаточных предложениях с полусоюзом, включающим указательное местоимение, глагол обычно стоит в одном из времен сослагательного наклонения (Эбрахими 1973. 44).

Кроме того, несмотря на высокую взаимозаменяемость обсуждаемых выше союзов, их стилевые рамки бывают весьма размыты. На основе проведенного нами статистического анализа с обзором более 1500 примеров употребления союзов одновременности мы можем сделать вывод, что وقتى كه [vaqti-ke] когда и его варианты в зависимости от стиля являются самыми употребительными из вышеуказанных союзов одновременности. В выборке присутствовало около 500 примеров разговорной речи (голосовые сообщения, фильмы, видео, скрипты личных бесед) и около 1000 примеров из письменных источников (СМИ, художественная литература, корпус персидского языка). Часть этих примеров продемонстрирована в практическом материале в Таблище 1.

В работе «Роль темпоральных союзов в определении временной взаимосвязи между текущими событиями» изложены исчерпывающие результаты проверки количества вхождений всех временны́х союзов в корпус 
персидского языка (Мортазавиния и др. 2011. 12), и в готовом рейтинге временны́х союзов وقتى [vaqti] когда находится на третьем месте по узуальности (2977 вхождений).

Несомненно, вышеупомянутые союзы можно считать наиболее простыми для передачи одновременности в сложноподчиненном предложении, хотя они могут также вводить предшествование или следование. Рассмотрим примеры использования подобных союзов в персидском языке с различными аспектами глагола:

\section{Таблица 1}

\begin{tabular}{|c|c|}
\hline Оригинал & Перевод и пояснение \\
\hline 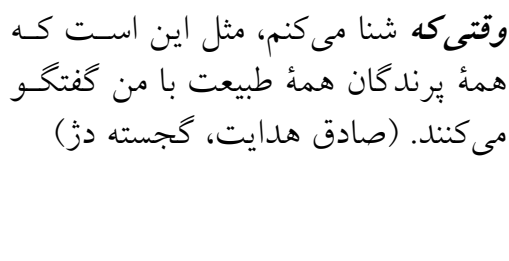 & $\begin{array}{l}\text { Когда я плаваю, мне кажется, что все } \\
\text { птицы, вся природа разговаривает со } \\
\text { мной. } \\
\text { Одновременность действий при глаголах } \\
\text { несовершенного вида. }\end{array}$ \\
\hline 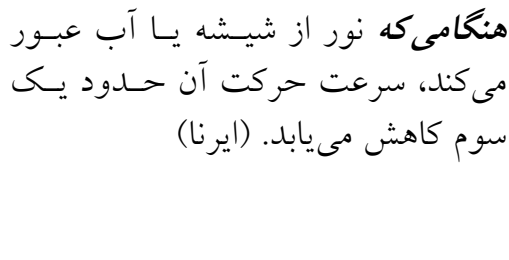 & $\begin{array}{l}\text { Когда свет проходит через стекло или } \\
\text { воду, его скорость уменьшается примерно } \\
\text { на треть. } \\
\text { Одновременность действий при глаголах } \\
\text { несовершенного вида. }\end{array}$ \\
\hline 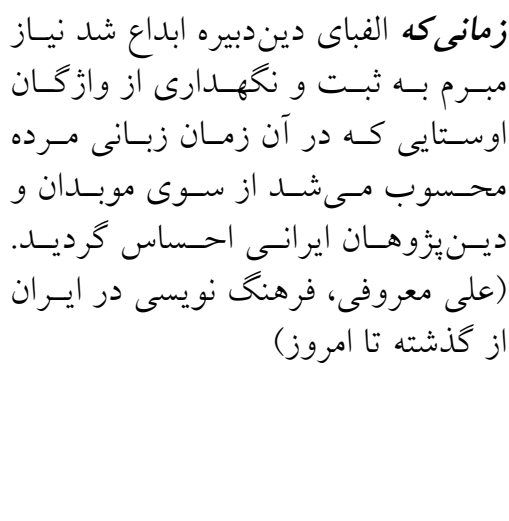 & 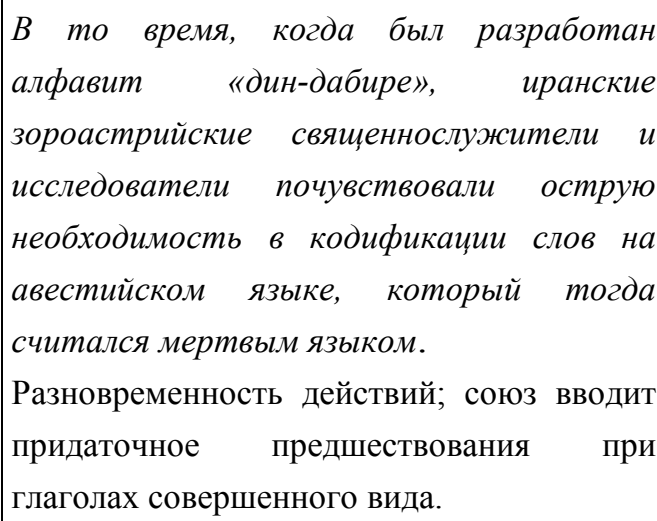 \\
\hline
\end{tabular}




\begin{tabular}{|c|c|}
\hline 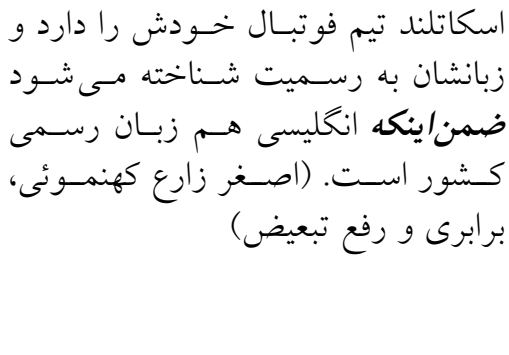 & $\begin{array}{l}\text { В Шотландии есть собственная } \\
\text { футбольная команда, шотландский } \\
\text { является официальным языком страны, но } \\
\text { в то же время английский также } \\
\text { считается официальным языком. } \\
\text { Одновременность действий при глаголах } \\
\text { несовершенного вида. }\end{array}$ \\
\hline 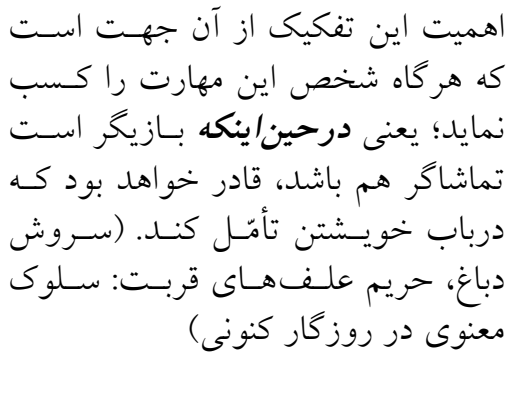 & $\begin{array}{l}\text { Важность этого разделения заключается } \\
\text { в том, что всякий раз, когда кто-либо } \\
\text { приобретает этот навык, то есть } \\
\text { может быть одновременно актером и } \\
\text { зрителем, он также может созерцать } \\
\text { себя со стороньл. } \\
\text { Одновременность действий при глаголах } \\
\text { несовершенного вида. }\end{array}$ \\
\hline 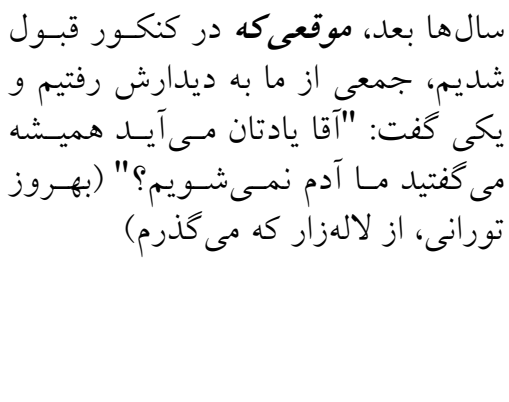 & $\begin{array}{l}\text { Спустя годы, успешно сдав } \\
\text { вступительный экзамен, некоторые из нас } \\
\text { пришли на встречу с ним. Кто-то сказал: } \\
\text { «А вы помните, как постоянно говорили, } \\
\text { что из нас ничего путного не выйдет?» } \\
\text { Разновременность действий; союз вводит } \\
\text { придаточное предшествования при } \\
\text { глаголах совершенного вида. }\end{array}$ \\
\hline
\end{tabular}

Как мы видим, аспект персидского глагола (завершенность как совершенный аспект, незавершенность - как несовершенный) также играет важную роль в установлении отношений одновременности или разновременности между грамматическими основами. При употреблении ряда форм несовершенного вида два не ограниченных пределом процесса сочетаются, что, как правило, приводит к отношению одновременности, в то время как сочетание нескольких глаголов совершенного вида обычно используется для выражения последовательности фактов (Шведова 1960, 605). 
Таким образом, при наличии в сложном персидском предложении глаголов в завершенных временах очень часто прослеживается вводимое союзом придаточное предшествования или следования.

\section{2 - Остальные союзы одновременности}

Воспользовавшись статистическими материалами по частотности союзов из работы «Роль темпоральных союзов в определении временно́̆ взаимосвязи между текущими событиями» (Мортазавиния и др. 2011. 12) мы завершили список всех существующих в современном персидском языке темпоральных союзов одновременности, добавив к рассмотренным выше следующие союзы:

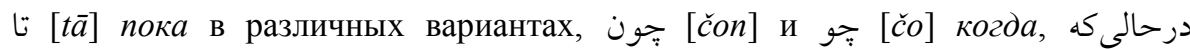
[dar-hāli-ke]в то время как, هடiآ[āngāh] когда; в тот момент во всех возможных вариантах написания, مادامى كه [mādāmi-ke] пока; до тех пор, пока в различных вариантах употребления. Примеры употребления указанных союзов, проанализированные в рамках составления настоящей статьи, приведены в Таблицее 2.

Таблица 2

\begin{tabular}{|c|c|}
\hline Оригинал & Перевод \\
\hline المثل ايرانى) آب نزنى، شناكر نمىشوى. (ضرب & $\begin{array}{l}\text { Пока не бросишься в воду - не } \\
\text { станешь пловцом. }\end{array}$ \\
\hline 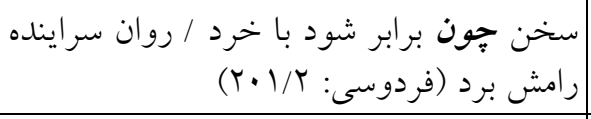 & $\begin{array}{l}\text { Когда сказанное не противоречит } \\
\text { рассудку, душа поэта полна радости. }\end{array}$ \\
\hline $\begin{array}{l}\text { Когда народ с песнью скрылся из вида } \\
\text { и слуха, тяжелое чувство тоски за } \\
\text { свое одиночество, за свою телесную } \\
\text { праздность, за свою враждебность к } \\
\text { этому миру охватило Левина. } \\
\text { (Л.Н.Толстой, Анна Каренина) }\end{array}$ & 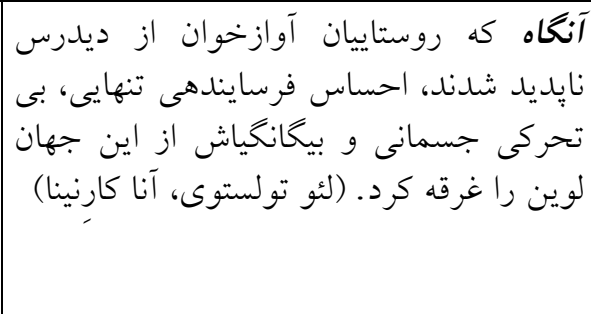 \\
\hline
\end{tabular}




\begin{tabular}{|c|c|}
\hline 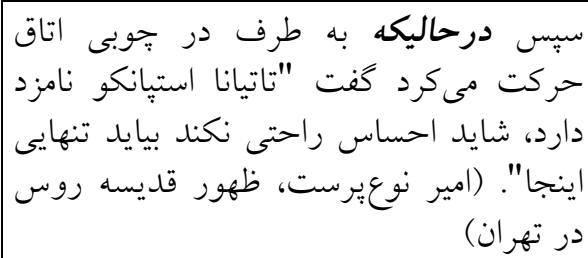 & $\begin{array}{l}\text { После этого она, приближаясь к } \\
\text { деревянной двери комнаты, сказала: } \\
\text { «У Татьяны Степаненко есть жених. } \\
\text { Возможно, ей не очень комфортно } \\
\text { приходить сюда одной». }\end{array}$ \\
\hline 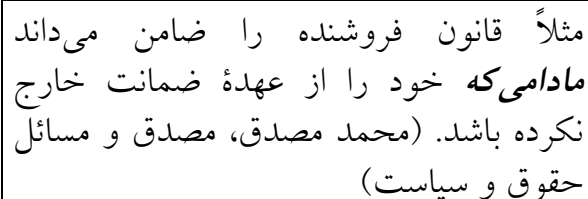 & $\begin{array}{l}\text { Например, закон рассматривает } \\
\text { продавиа как гаранта до того } \\
\text { момента, пока сам не снимает с себя } \\
\text { обязанности по гарантии. }\end{array}$ \\
\hline
\end{tabular}

\section{2. Союзы одновременности в русском языке}

Как и в персидском языке, союзы русского языка по значению классифицируются на сочинительные и подчинительные. По словам синтаксистов-русистов, сложносочиненные предложения в русском языке чаще других выражают именно временные отношения (Валгина 2000. 297). Тем не менее, в данном разделе мы также не будем рассматривать функцию передачи одновременности у сочинительных союзов.

Н.С. Валгина предлагает список союзов, используемых при выражении одновременности в сложноподчиненных предложениях: когда, пока, как, покамест (архаич.), покуда (прост.), в то время как (Валгина 2002. 316). В. Ю. Апресян и О.Е. Пекелис указывают малоузуальный союз по мере того как в одном ряду с другими союзами одновременности. Таким образом, в настоящей работе мы рассмотрим всего семь подчинительных союзов одновременности, из которых два имеют функционально-стилевую окраску, а пять являются языковыми единицами нулевого уровня. При этом все рассматриваемые союзы являются семантическими (Белошапкова 1989. 526).

\section{1 - Союз когда}

Когда считается наиболее частотным темпоральным союзом русского языка (581566 вхождений в Основном корпусе на 26.03.2020). Функционал 
данной лексемы огромен, она может использоваться в роли служебного слова как в рамках возможностей союза, так и частицы, образовывать союзную скрепу и использоваться как временно́е наречие. Помимо придаточных времени, когда может также присоединять условные придаточные; при присоединении первых союз когда указывает на одновременность действий, протекающих в главной и зависимых грамматических основах, их повторяемость, начальный момент действия или следование действий друг за другом. Кроме того, союз когда выражает одновременность без подчеркивания совпадения во времени действий главной и придаточной частей (Валгина 2002. 316).

Сравним вводимую союзом однократную и повторяющуюся одновременность и действий на примерах:

\section{Таблица 3}

\begin{tabular}{|c|c|}
\hline Пример & Пояснение \\
\hline $\begin{array}{l}\text { За два-три дня до первого снега, когда днём } \\
\text { было ещё по-осеннему жарко и безоблачно и } \\
\text { о близкой зиме никому не хотелось думать, } \\
\text { стланик вдруг растягивал по земле свои } \\
\text { огромные, двухсаженные лапь <...>. } \\
\text { (В.Т.Шаламов. Кольмские рассказы) }\end{array}$ & $\begin{array}{l}\text { Союз когда вводит } \\
\text { придаточное одновременности } \\
\text { с повторяющимся действием. }\end{array}$ \\
\hline $\begin{array}{l}\text { Вылетайте, - заговорил Азазелло в трубке, } \\
\text { и по тону его было сльишно, что ему } \\
\text { приятен искренний, радостный порыв } \\
\text { Маргариты, - когда будете пролетать над } \\
\text { воротами, крикните: «Невидима!» (М.А. } \\
\text { Булгаков. Мастер и Маргарита) }\end{array}$ & $\begin{array}{l}\text { Союз когда вводит } \\
\text { придаточное одновременности } \\
\text { с разовым действием. }\end{array}$ \\
\hline
\end{tabular}

Использование союза когда в придаточном предложении в связке с наречием тогда дополнительно делает акцент на непосредственное временно́ 
согласование: Когда она от нас отошла, тогда я шепнул Григорью Александровичу: «Ну что, какова?» (М.Ю.Лермонтов. Герой намего времени).

\section{$2.2-$ Союз как}

Лексема как также может выступать морфологически как наречие, союз и частица. Основной функционал союзной формы данной лексемы приходится на присоединение сравнительных оборотов в составе простого предложения или сравнительных придаточных предложений в рамках сложноподчиненного предложения. В настоящее время использование союза как для введения придаточного одновременности используется редко и считается архаичным, но в классической русской литературе осталось множество примеров его употребления в указанном значении (Виноградов 1960. 301). Приведем один из них, относящийся к середине XIX века: Как я вышел из одиночества, не стало пустоты около меня <... (Г.С. Батеньков. Заметки к труду «Общая философия системы мира»).

\section{3- Союзы пока, покуда, покамест}

По мнению В.Ю. Апресян и О.Е. Пекелис союз пока является наиболее частотным из всех союзов одновременности русского языка, что происходит благодаря его нейтральности, отсутствующей у его стилистических синонимов покамест и покуда.

Союз пока может выражать одновременность действия или его временно́̆ предел. Союз покуда считается просторечным и устаревшим, находя очень слабую репрезентацию в современной литературе, а покамест - разговорным и устаревшим, редко встречаясь даже в классических литературных памятниках на русском языке.

При использовании глаголов несовершенного аспекта в главном и придаточном предложениях указанные союзы дополнительно подчеркивают 
совпадение времени совершения действия (Виноградов 1960. 300). В Таблище 4 мы привели примеры использования всех рассматриваемых союзов по указанной схеме:

Таблица 4

\begin{tabular}{|c|c|}
\hline Пример & Пояснение \\
\hline $\begin{array}{l}\text { Там шёл спектакль, пока я читал свою } \\
\text { пьесу. (М.А. Булгаков. Театральньй } \\
\text { роман) }\end{array}$ & \multirow[t]{3}{*}{$\begin{array}{l}\text { Сказуемые главной и придаточной } \\
\text { части находятся в несовершенном } \\
\text { виде. }\end{array}$} \\
\hline $\begin{array}{l}<\ldots>\text { сама хочу быть вполне } \\
\text { свободною, покамест у меня хоть } \\
\text { какой-нибудь свой кусок да такие дети, } \\
\text { как ть } и \text { Дунечка. } \\
\text { (Ф.М. Достоевский. Преступление и } \\
\text { наказание) }\end{array}$ & \\
\hline $\begin{array}{l}\text { Всё время, покуда тело бабушки стоит } \\
\text { в доме, я испьтываю тяжёлое чувство } \\
\text { страха смерти <..>. (Л.Н. Толстой. } \\
\text { Отрочество) }\end{array}$ & \\
\hline
\end{tabular}

\section{4 - Союзы по мере того как и в то время как}

Сложный союз по мере того как малочастотен в современном русском языке (2 448 вхождений в Основном корпусе на 30.03.2020).Данный союз не только указывает на одновременность параллельных действий, но и на постепенно развивающуюся ситуацию в главном предложении на фоне действия в придаточном предложении: По мере того как я раскручивал проволоку, пробка всё сильней и сильней давила на ладонь моей руки и подымалась, как сильное одушевлённое существо. (Ф.А. Искандер. Летним днем). 
Временно́е значение малочастотного союза в то время как максимально близко к значению одновременности союза когда. Стоит отметить, что рассматриваемый союз также употребляется в уступительном значении. Во временно́м значении данная лексема демонстрирует параллельное развитие нескольких действий при любых аспектных сочетаниях глаголов. При этом при глаголах совершенного вида союз в то время как дополнительно подчеркивает момент временно́го совпадения придаточной и главной частей предложения: Сразу после института Лёвка поехал в Бамкирию $u$ проработал там три года на промыслах, в то время как Дмитриев <..> остался работать в Москве на газовом заводе, в лаборатории. (Ю.В. Трифонов. Обмен).

\section{3. Лингвостилистический анализ союзов одновременности русского и персидского языков}

В рамках данной части мы рассматриваем лингвостилистику союзов одновременности - один из трех основных лексическим уровней любого языка (Ахманова 2004. 488) с целью выявления эквивалентных слов в двух языках в рамках практической стилистики. Переводческая эквивалентность подразумевает обязательное наличие в переводе эмотивных, стилистических и др. единиц текста оригинала, а союзы также могут нести в себе стилистическую составляющую (Комиссаров 1980. 152).

\section{1 - Разговорный стиль}

В разговорном стиле может использоваться как нормированная разговорная лексика, так и внелитературная лексика (диалектизмы, просторечия, жаргонизмы и др.). Безусловно, разговорная речь тяготеет к максимальной сжатости и лаконичности высказывания, в связи с чем наиболее короткие персидские союзы تا تاā] пока и وقتى [vaqti] когда можно назвать 
одними из наиболее популярных в современной иранской речи. Тем не менее, заметно чаще других в разговорной речи на персидском языке можно встретить вариант وقتى كه маркированный разговорным стилем узуальный союз موقعى كه [mowqei-ke] когда.

В русском языке при наличии меньшего разнообразия союзов малоузуальными в нормированной разговорной речи можно назвать лишь в то время как и по мере того как. При этом три союза одновременности покамест, покуда и как, - относятся к внелитературной лексике: употребление всех трех в современном узусе является просторечным. Таким образом, лексемы нулевого уровня когда и пока являются наиболее частотными в узусе русской нормированной разговорной речи.

Как носители персидского, так и носители русского языка могут быть подвержены влиянию канцеляризма и использовать в разговорной речи союзы, предназначенные для официально-делового стиля, рассматриваемого далее.

\section{2 - Книжные стили речи}

3.2.1 - Художественный стиль. Многолетняя история развития персидского языка значительно повлияла на вокабуляр языка и, в частности, на служебные части речи: многие из рассматриваемых союзов использовались даже в древней персидской поэзии, и иногда их выбор был обусловлен последовательностью длинных и кратких гласных в союзе, что было необходимо для создания ритмики стиха. Наиболее частую репрезентацию в древней персидской поэзии имеют краткие союзы جون $[\check{c}$ : مادام $[$ [mādām] пока; до тех пор.

Современная иранская художественная литература апеллирует ко всему массиву имеющихся союзов одновременности в зависимости от жанра. Аппарат союзов-синонимов وقتى كه 
придаточные одновременности, избегая лексических повторов. Союз موقعى كه [mowqe'i-ke] когда считается более разговорным и употребляется в художественной речи в основном для передачи коммуникации книжных героев.

Архаичные союзы как, покуда и покамест находят богатую репрезентацию в классической русской литературе, в период написания памятников которой они употреблялись в нормированной разговорной речи. В современной литературе они используются лишь для стилизации языка более ранних эпох или передачи просторечий. Наиболее узуальными союзами одновременности в современной литературе на русском языке остаются частотные когда и пока, что ярко демонстрируется количеством вхождений указанных лексем 163769 и 47067 соответственно - в подмножество художественный текстов, написанных с 1950 по 2020 год, Национального корпуса русского языка. В свою очередь, у архаичных синонимов в данном подмножестве гораздо меньше вхождений - 1323 для покуда и 263 для покамест. Оценка узуальности употребления временного значения союза как затруднена в связи с его многозначностью.

3.2.2 - Публицистический стиль. Публицистический стиль характеризуется особыми формами реализации и стилистическими функциями. По этой причине стиль СМИ вовлекает языковые единицы любых уровней и стилей языка (Розенталь 205. 408). Нормативные информационные тексты пользуются языковыми единицами нулевого уровня, однако иные жанры публицистики апеллируют ко всему аппарату имеющихся языковых возможностей.

Стоит отметить, что среди союзов персидского языка наблюдается функционально-стилевое расслоение, однако ни один из союзов не обладает эмоциально-экспрессивной окраской. Таким образом, в рамках публицистического стиля журналист при помощи союзов может лишь 
стилизовать текст, но не придать ему эмоциональную окраску. Таким образом, иранские публицистические тексты могут быть стилизованы с помощью стилистически окрашенной лексики или быть написаны в логичной информативной форме с помощью союзов, используемых также в официально-деловом и научном стилях. Предпочтение СМИ отдается раздельным вариантам написания компонентов союза, рекомендуемым Академией персидского языка и литературы (Фархангестан 2015. 22).

Подобная ситуация складывается и с союзами русского языка: журналист может воспользоваться стилистически окрашенными устаревшими внелитературными союзами покамест, покуда и как для стилизации текста или использовать союзы нулевого уровня для создания нормативных информационных текстов.

3.2.3 - Официально-деловой и научный стили. Язык иранской документации и научных публикаций тяготеет к лексической избыточности и канцеляризму, что влияет на выбор союзов: в основном предпочтение отдается стилистически более высоким هنخامى كمن اين كه, هingemn-e-in-

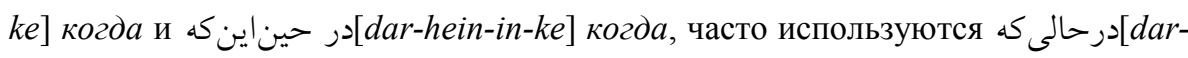
hāli-ke]в то время как (что в рамках данных стилей речи часто переводится на русский деепричастным оборотом), تاā] пока и زمانى كه [zamāni-ke] когда. Безусловно, возможно применение и других единиц нулевого уровня. Как и в случае с публицистическим стилем, на сегодняшний день предпочтение отдается раздельному написанию вспомогательных компонентов союза.

В русском языке основным критерием выбора союза для использования в текстах указанных стилей также остается стилистическая нейтральность, так как они не приемлют иностилевых вкраплений (Валгина 2002. 28). Союз по мере того как чаще встречается в научных текстах, т.к. показывает постепенность разворачивающегося процесса на фоне другого. Союз в то время как редко используется в указанных стилях для введения придаточного 
одновременности, чаще употребляясь в своем первом значении ведения противопоставления. Единица нулевого уровня пока употребляется на порядок реже когда, т.к. авторы текстов подобных стилей избегают любых неправильных толкований; этот же союз может также восприниматься как вводящий временно́й предел. Союз когда в силу своей универсальности и нейтральности является самым узуальным также и в рамках рассматриваемых стилей (Апресян, Пекелис. 2012).

\section{Заключение}

Аппараты темпоральных союзов одновременности персидского и русского языков отличаются друг от друга квантативными показателями (одиннадцать союзов в персидском языке, семь в русском), в результате чего на любой союз русского языка приходится сразу несколько союзов персидского языка. Союзы обоих языков лишены эмоционально-экспрессивной окраски, но не все из них являются стилистически нейтральными, в связи с чем часть рассмотренных союзов маркирована одним или несколькими стилями речи.

Наиболее частотным персидским союзом одновременности является многозначный союз وقتى количеством синонимов-дублетов и стилистических синонимов. Его эквивалентом в русском языке является многозначный союз когда нулевого языкового уровня, который широко применяется во всех стилях речи.

Рекордсменами по узуальности в нормированной разговорной речи персидского языка являются наиболее краткие союзы تا تاā] пока и وقتى когда в различных вариациях, а также функционально-стилистически маркированный союз موقعى كه когда. В художественном и публицистическом стилях речи автор может апеллировать ко всему массиву союзов одновременности в целях передачи нормированной речи или стилизации текста. В официально-деловых и 
научных текстах на персидском языке на передний план выходят функционально-стилистически окрашенные союзы هiخامى [hengāmi-ke] когда, ضمن اين كه [zemn-e-in-ke] когда и др.; в русском же языке в указанных стилях сохраняется главенствование союзов когда и пока, однако в научном стиле бо́льшую узуальность приобретает союз по мере того как.

\section{Литература}

1- Мортазавиния М., Бижанха̄н М. и др., Парвинсададат (1390/2011). Нагш-е хуруф-е рабт-е зама̄н да̄p таин-е рфбете-йе зама̄ни бейн-е руйда̄д-ха̄-йе фели дар пейкар-ейе мутун-е заба̄н-е фа̄рси-йе моа̄сер. До фаслна̄ме-йе парда̄зеш-е ала̄’ем-ва-да̄де-ха̄. шома̄ре-йе 1, пейа̄пей 15, с. 9-16.

2- Амид Хосейн (1394/2015). Фарханг-е фарси-йе Амид. Тегеран: Ентешарат-е Амир-Кабир.

3- Апресян В.Ю., Пекелис О.Е. (2012). Подчинительные союзы. Материалы для проекта корпусного описания русской грамматики (http://rusgram.ru). На правах рукописи. - М.

4- Ахманова О.С. (2004). Словарь лингвистических терминов. - М.: Едиториал УPCC. $-574 \mathrm{c}$.

5- Бурцева В.В. (2005). Словарь наречий и служебных слов русского языка. М.: Рус.яз. -Медиа. - 750 с.

6- Валгина, Н.С. (2000). Синтаксис современного русского языка: Учебник. М.: Агар. - 416 c.

7- Вахидиян-Камйар Таги (1397/2018). Дастур-е заба̄н-е фа̄pcu (1). Тегеран: Самт.

8- Грамматика русского языка. Т. 2: Синтаксис. Ч. 2 / под ред. Виноградова, В.В. и др. (1960). - М.: Издательство АН СССР. — 440 с.

9- Ефремова Т.Ф. (2020). Толковый словарь служебных частей речи русского языка. - М.: Астрель: АСТ. 2004. - 814 с. Режим доступа: http://www.efremova.info/

10- Ибрагими Хамид (1388/2009). Негареш-е пишрафте (виже-йе забан-амузан-е гейре ирани). Гом: Ентешарат-е Нехзат.

11- Комиссаров В.Н. (1980). Лингвистика перевода. - М.: Междунар. отношения. $-166 \mathrm{c}$.

12- Моин Мохаммад (1391/2012). Фарханг-е фа̄pcu. Тегеран: Ентешарат-е АмирКабир. 
13- Национальный корпус русского языка [Электронный ресурс]. - Режим доступа: http://www/ruscorpora.ru/

14- Прияткина А.Ф., Стародумова Е.А. и др. (2001). Словарь служебных слов русского языка. - Владивосток: Примполиграфкомбинат. - 363 с.

15- Розенталь А.А., Джанджакова Е.В., Кабанова Н.П. (2013). Справочник по русскому языку: правописание, произночение, литературное редактирование. — М.: Айрис-пресс. — 496 с.

16- Рубинчик Ю.А. (2001). Грамматика современного персидского литературного языка. - М.: Издательская фирма «Восточная литература» PAH. $-600 \mathrm{c}$.

17- Русская грамматика. Т.1. Фонетика. Фонология. Ударение. Интонация. Словообразование. Морфология / под ред. Шведовой, Н.Ю. и др. (1980). - М.: Издательство «Наука». - 783 с.

18- Современный русский язык: Учебник / под ред. Валгиной, Н.С. (2002). - М.: Логос. -528 с.

19- Современный русский язык: Учебник для филологов спей. университетов / под ред. Белошапковой, В.А. (1989). — М.: Высшая школа. — 800 с.

20- Фархангеста̄н-е заба̄н-о-адаб-е фа̄рси (1394/2015). Дастур-е хатm-е фа̄pcu. Тегеран: Фархангеста̄н-е заба̄н-о-адаб-е фа̄рси.

21- Фаршидвард Хосро (1392/2013). Дастур-е мофассал-е емруз. Тегеран: Ентешарат-е Сохан.

22- Халил-Хатиб Рахбар (1397/2018). Кетаб-е хуруф-е езафе-ва-рабт. Тегеран: Саади (Сара̄-йе Ахаван).

23- Шахматов А.А. (2001). Синтаксис русского языка. - М.: Эдиториал УРСС. $-624 \mathrm{c}$.

\section{Bibliography}

1- Mortazavinija M., Bizhanhān M. i dr., Parvinsadadat (1390/2011). Nagsh-e huruf-e rabt-e zamān dār tain-e rfbete-je zamāni bejn-e rujdād-hā-je feli dar pejkar-eje mutun-e zabān-e fārsi-je moāser. Do faslnāme-je pardāzesh-e alā'em-va-dāde-hā. shomāre-je 1, pejāpej 15, s. 9-16.

2- Amid Hosejn (1394/2015). Farhang-e farsi-je Amid. Tegeran: Entesharat-e AmirKabir.

3- Apresjan V.Ju., Pekelis O.E. (2012). Podchinitel'nye sojuzy. Materialy dlja proekta korpusnogo opisanija russkoj grammatiki (http://rusgram.ru). Na pravah rukopisi. $-\mathrm{M}$. 
4- Ahmanova O.S. (2004). Slovar' lingvisticheskih terminov. - M.: Editorial URSS. $-574 \mathrm{~s}$.

5- Burceva V.V. (2005). Slovar' narechij i sluzhebnyh slov russkogo jazyka. — M.: Rus.jaz. -Media. - $750 \mathrm{~s}$.

6- Valgina, N.S. (2000). Sintaksis sovremennogo russkogo jazyka: Uchebnik. - M.: Agar. - $416 \mathrm{~s}$.

7- Vahidijan-Kamjar Tagi (1397/2018). Dastur-e zabān-e fārsi (1). Tegeran: Samt.

8- Grammatika russkogo jazyka. T. 2: Sintaksis. Ch. 2 / pod red. Vinogradova, V.V. i dr. (1960). — M.: Izdatel'stvo AN SSSR. — $440 \mathrm{~s}$.

9- Efremova T.F. (2020). Tolkovyj slovar' sluzhebnyh chastej rechi russkogo jazyka. — M.: Astrel': AST. 2004. — 814 s. Rezhim dostupa: http://www.efremova.info/

10- Ibragimi Hamid (1388/2009). Negaresh-e pishrafte (vizhe-je zaban-amuzan-e gejre irani). Gom: Entesharat-e Nehzat.

11- Komissarov V.N. (1980). Lingvistika perevoda. - M.: Mezhdunar. otnoshenija. $166 \mathrm{~s}$.

12- Moin Mohammad (1391/2012). Farhang-e fārsi. Tegeran: Entesharat-e Amir-Kabir.

13- Nacional'nyj korpus russkogo jazyka [Jelektronnyj resurs]. - Rezhim dostupa: http://www/ruscorpora.ru/

14- Prijatkina A.F., Starodumova E.A. i dr. (2001). Slovar' sluzhebnyh slov russkogo jazyka. - Vladivostok: Primpoligrafkombinat. - $363 \mathrm{~s}$.

15- Rozental' A.A., Dzhandzhakova E.V., Kabanova N.P. (2013). Spravochnik po russkomu jazyku: pravopisanie, proiznoshenie, literaturnoe redaktirovanie. - M.: Ajris-press. - $496 \mathrm{~s}$.

16- Rubinchik Ju.A. (2001). Grammatika sovremennogo persidskogo literaturnogo jazyka. — M.: Izdatel'skaja firma «Vostochnaja literatura» RAN. — $600 \mathrm{~s}$.

17- Russkaja grammatika. T.1. Fonetika. Fonologija. Udarenie. Intonacija. Slovoobrazovanie. Morfologija / pod red. Shvedovoj, N.Ju. i dr. (1980). - M.: Izdatel'stvo «Nauka». - $783 \mathrm{~s}$.

18- Sovremennyj russkij jazyk: Uchebnik / pod red. Valginoj, N.S. (2002). - M.: Logos. - $528 \mathrm{~s}$.

19- Sovremennyj russkij jazyk: Uchebnik dlja filologov spec. universitetov / pod red. Beloshapkovoj, V.A. (1989). — M.: Vysshaja shkola. — $800 \mathrm{~s}$.

20- Farhangestān-e zabān-o-adab-e fārsi (1394/2015). Dastur-e hatt-e fārsi. Tegeran: Farhangestān-e zabān-o-adab-e fārsi.

21- Farshidvard Hosro (1392/2013). Dastur-e mofassal-e emruz. Tegeran: Entesharat-e Soxan. 
22- Halil-Hatib Rahbar (1397/2018). Ketab-e huruf-e ezafe-va-rabt. Tegeran: Saadi (Sarā-je Ahavan).

23- Shahmatov A.A. (2001). Sintaksis russkogo jazyka. - M.: Jeditorial URSS. - 624 s.

HOW TO CITE THIS ARTICLE

Шафаги, М., \& Горячковская, Т. (2021). Linguistic Analysis of the Simultaneity Conjunctions of the Russian and Persian

Languages. Issledovatel'skiy Zhurnal Russkogo Yazyka I Literatury, $9(1)$. 143-165.

DOI: $10.52547 /$ iarll.17.143

URL: https://www.journaliarll.ir/index.php/iarll/article/view/146

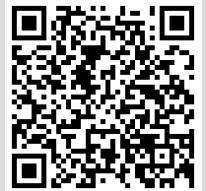




\title{
تحليل زبانى و سبكى حروف ربط همزمانى در زبانهاى روسى و فارسى
}

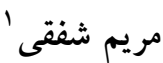 \\ دانشيار زبان روسى دانشخاه علامه طباطبائى،

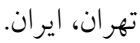

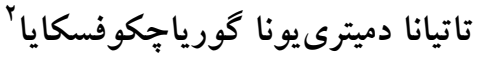

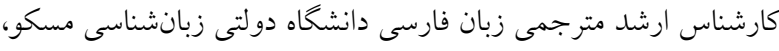

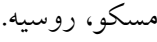

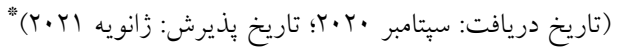

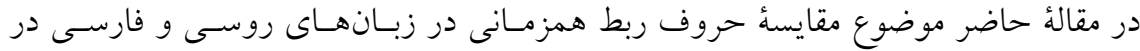

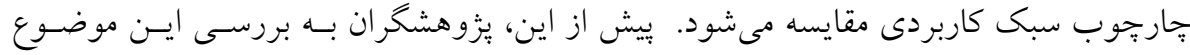

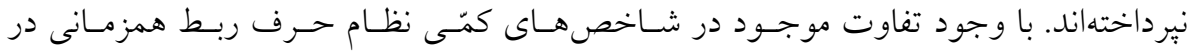

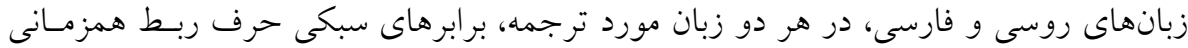

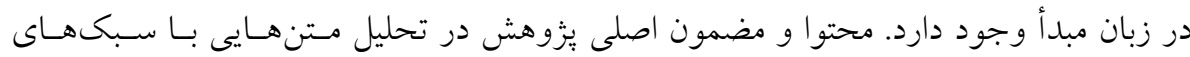

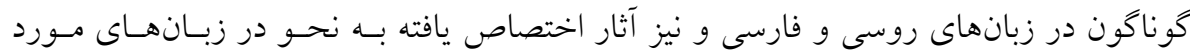

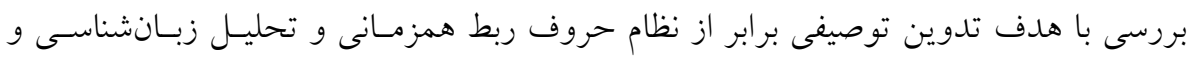

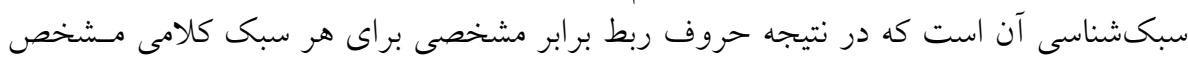

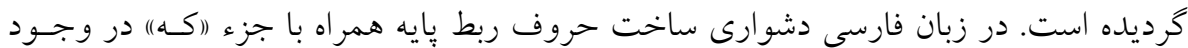

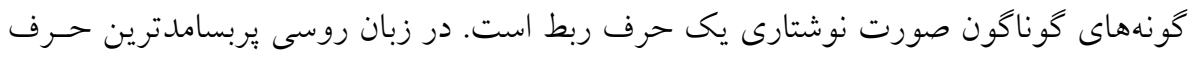

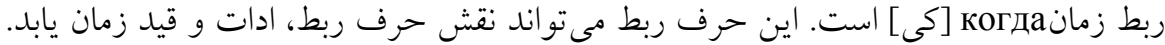

وازگًان كليدى: جملهُ بيرو، حرف ربط وابسته، معادل ترجمه، سـبكشناسى كـاربردى، عمل

همزمان.

1. E-mail: shafaghi@atu.ac.ir

2. E-mail: tatyana.goryachkovskaya@mail.ru 